\title{
Fruit and Oil Characteristics of Olive Candidate Cultivars from Turkey
}

\author{
Yasin OZDEMIR ${ }^{1}$, Aysun OZTURK ${ }^{1}$, Engin GUVEN ${ }^{1}$, Muge ASAN NEBIOGLU ${ }^{2}$, Nesrin \\ AKTEPE TANGU ${ }^{3}$, Mehmet Emin AKCAY ${ }^{3}$, Sezai ERCISLI ${ }^{4 *}$ \\ ${ }^{1}$ Ataturk Central Horticultural Research Institute, Department of Food Technologies, Yalova, Turkey \\ ${ }^{2}$ Central Research Institute of Food and Feed Control, Bursa, Turkey \\ ${ }^{3}$ Ataturk Central Horticultural Research Institute, Department of Fruit Breeding, Yalova, Turkey \\ ${ }^{4}$ Ataturk University, Agricultural Faculty, Department of Horticulture,Erzurum, Turkey; sercisli@atauniedu.tr ("correspondingauthor)
}

\begin{abstract}
This is the first study in Turkey that evaluated olive fruit and oil characteristics of 23 cultivar candidates selected among 393 olive genotypes, on the bases of agronomical characteristics; the candidate cultivars were obtained by cross breeding between standard cultivars ('Gemlik', 'Edinciksu', 'Uslu', 'Tavşan Yüreği', 'Karamürselsu') and foreign cultivars ('Lucques', 'Belle d'Espagne' and 'Manzanilla'). Fruit traits such as fruit weight, flesh to seed ratio, fruit and seed size, as well as oil characteristics such as moisture, oil content, specific absorption at ultraviolet light, free acid content, peroxide value, chlorophyll and fatty acid composition were determined. Fruits and oils of intensely cultivated 'Gemlik' and 'Ayvalık' olive cultivars were also analyzed to compare them with the new candidate cultivars. According to the oil content, 'GE067' (23.30\%), 'GE181' (23.97\%), 'GE366' (22.52\%), 'GE417’ (22.16\%), 'GT009' (24.14\%), 'GT014' (21.02\%), 'GU247’ (22.48\%), 'GU320' (27.15\%) and 'GU434' (21.89\%) gave better results, thus having good potential for registration as new cultivars for oil production. 'GE366' and 'GU434' were determined as the best cultivar candidates for producing dual purpose olives (table olives and oil). 'GE363' had the best fatty acid composition, which is an important feature in terms of oxidative stability and disease prevention.
\end{abstract}

Keywords: cultivar registration, fruit dimensions, fatty acids, olive genotype, selection

\section{Introduction}

The olive tree (Olea europaea L.) is one of the most important fruit trees in the Mediterranean countries. Olive oil and table olives are important components of the Mediterranean diet and are greatly consumed worldwide. The Mediterranean region is the major international olive-growing area, accounting for almost $95 \%$ of the world's olive tree plantations. The biggest olive-producing countries in the Mediterranean region are Spain, Italy, Greece and Turkey (FAO, 2012).

Olive cultivars are generally identified by morphological traits regarding habitus and fruit or by oil characteristics (Kaya and Tekintas, 2006). Most of the olive breeding programs have focused to improve the quality of olive oil, but few were initiated in order to obtain quality table olives (León et al.,2011; Ozdemir and Kurultay, 2015). Fruit size is a critical character for selection of olive cultivar candidates (Padula $e t$ al.,2008). Selection steps of olive breeding programs lead to achieving outstanding cultivars and eliminate others which do not have the potential to increase quality of produced olive oil or table olives (Sánchez de Medina et al, 2015). Classic breeding programs based on crossing and selection within the progenies were conducted in
Turkey (Arsel and Cirik, 1994; Ozdemir et al., 2013), Tunisia (Trigui 1996), Greece (Pritsa et al, 2003), Spain (León et al., 2011) and Italy (Bellini $e t$ al., 2002). Several new cultivars were registered after such cross breeding programs (Bellini et al., 2008; Roca $e t$ al., 2011; Lavee et al., 2014). In olive breeding, oil and dry matter content analysis of fruits and specific absorbance at UV light, peroxide value, fatty acid and free acid content analysis of oil are mostly used to select the best cultivar candidates (Ranalli et al., 2000; Ripa et al, 2006). Researchers reported that there still is potential to increase the income of olive farmers and processors, consumer health and reduce environmental pollution by developing novel olive cultivars (Lavee, 1990; Padula et al., 2008; Ozdemir et al.,2013).

The aim of the current research was to determine fruit characteristics and the main components of olive oil for cultivar candidates obtained by different crossing combinations among Turkish and foreign olive cultivars, through the breeding program initiated in 1990 at Ataturk Central Horticultural Research Institute Yalova/Turkey. According to agronomic characteristics, these candidate cultivars previously had been reported as potential genotypes for cultivar registration (Aktepe Tangu et al., 2008; Ozdemir et al.,2011). 
148

\section{Materials and Methods}

\section{Material}

In this study, 23 olive candidate cultivars with determined genitors were evaluated (Table 1). These trees were planted at a 1.5 $\times 3 \mathrm{~m}$ distance in olive genotype observation orchard from Ataturk Central Horticultural Research Institute (Yalova/Turkey). The investigated genotypes were chosen on the basis of their high productivity and agronomic characteristics, among 492 olive genotypes.

Olives were hand-picked at 3-5.3 maturation index, which provide optimum oil yield and quality (Kiristakis, 1998; Boskou, 2006) in harvest seasons of 2011/2012, 2012/2013 and 2014/2015. Fruits of 'Gemlik' and 'Ayvalık' cultivars were harvested from observation orchard of Ataturk Central Horticultural Research Institute (Yalova/Turkey) and observation orchard of Olive Research Institute (Izmir/Turkey).

\section{Fruit analysis}

Maturation index of olives was determined according calculation method of Hermoso et al. (1991) by using the color of olive skin and flesh. Fruit weight and flesh to seed ratio were established according to official method TS 774 (1992). Fruit weight was determined by weighting 100 olive fruits. Flesh to seed ratio was calculated by using the ratio of flesh and seed weight of 100 olive fruits. Fruit and seed size were measured by using digital caliper (Mitutoyo, Japan).

Before the oil analysis, olive seeds were removed, after which olives were crushed and dried. Oil of the dried olive paste was extracted by soxhlet apparatus, for at least 8 hours, with petroleum ether extraction at $50^{\circ} \mathrm{C}$ (Cemeroglu, 2007).

\section{Obtainingolive oil}

Olives were washed without delay; diseased and damaged olives were removed. Then olives were turned into paste by laboratory scale hammer (100 rev/min) and kneader (45 minutes) after which $0.5 \mathrm{~kg}$ batches of olive paste was put into press cloth and pressed $\left(250-300 \mathrm{~kg} / \mathrm{cm}^{2}\right)$ with a hydraulic press. Liquid phase from press was separated into water and oil phase by using separatory funnel. The obtained oil was centrifuged $(8,000 \mathrm{rev} / \mathrm{min})$ and filtered through a coarse filter $(20 \mu \mathrm{m})$. Finally, oil was filled into dark glass bottles without any air space and stored at $4^{\circ} \mathrm{C}$ until analyze.

\section{Oilanalysis}

Free acid content and peroxide value were assessed by titrimetric methods according to the official methodologies of
Turkish Food Codex - Communiqué of Analysis Methods of Olive Oil and Pomace Oil (Anonymous, 2015). For determination of specific absorbance value, $0.5 \mathrm{~g}$ of oil were weighted (with 0,0001 accuracy) and dissolved into $50 \mathrm{~mL}$ cyclohexane $50 \mathrm{~mL}$. Mixture was put into $1 \mathrm{~cm}$ quartz cuvette and its absorbance was measured at 232 and $270 \mathrm{~nm}$ with spectrophotometer (Hitachi, Japan).

Chlorophyll content was determined by spectrophotometric method according to Kiritsakis (1998). Olive oil samples were put into quartz cuvette and absorbance values were taken at 630 , 670 and $710 \mathrm{~nm}$ against carbon tetrachloride. The chlorophyll content was calculated by the following formula: Chlorophyll content $(\mathrm{mg} / \mathrm{kg})=$ $=[\mathrm{A} 670-(\mathrm{A} 630+\mathrm{A} 710) / 2] / 0.901 \mathrm{~L}$

where: $A=$ the absorbance value of the oil sample; $L=1 \mathrm{~cm}$ length tub.

Fatty acid methyl ester composition was determined by gas chromatography according to Anonymous (2015). $0.2 \mathrm{~g}$ oil and $10 \mathrm{ml}$ of hexane were put into a vial and shaken. After that, 0.5 $\mathrm{ml}$ of a methanolic $\mathrm{KOH}$ solution $(2 \mathrm{~N})$ was added and stirred. $0.5 \mu \mathrm{l}$ were taken from the upper phase and injected into the gas chromatography (Hewlett-Packard, USA).

Saturated fatty acids (SFA), monounsaturated fatty acids (MUFA) and polyunsaturated fatty acids (PUFA), MUFA / PUFA, linoleic acid (LA)/linolenic acid (LNA) and iodine number (IN) of olive oil samples were determined by using their fatty acid composition (Kyriakidis and Katsiloulis, 2000). The formulas used in the calculation are given below:

SFA $(\%)=$ palmitic acid + stearic acid + arashidic acid + behenic acid

MUFA (\%) = palmitoleic acid + oleic acid + eicosenoic acid

PUFA $(\%)=$ linoleic acid + linolenic acid

$\mathrm{IN}=0.93 \times($ oleic acid + eicosenoic acid $)+1.35 \times($ linoleic acid $)+2.62 \times($ linolenic acid $)$

\section{Statistical analysis}

Research plan was established according to completely randomized design and trial was performed in 3 replications. The data obtained throughout 3 years were determined whether there was a significant difference among the characteristics of samples with the analysis of variance. If significant differences were found between the samples' characteristics, they were further evaluated by testing with Fischer LSD test of multiple comparison procedure. The significance value was taken as 0.05 . Analyses were performed using the GLM procedure of SAS statistical software package program.

Table 1. Evaluated olive genotypes and their genitors

\begin{tabular}{|c|c|c|c|c|c|}
\hline No & Genotype & Crossing combination & No & Genotype & Crossing combination \\
\hline 1 & GE061 & Gemlik $\times$ Edinciksu & 13 & GU358 & Gemlik $\times$ Uslu \\
\hline 2 & GE067 & Gemlik $\times$ Edinciksu & 14 & GU429 & Gemlik $\times$ Uslu \\
\hline 3 & GE073 & Gemlik $\times$ Edinciksu & 15 & GU434 & Gemlik $\times$ Uslu \\
\hline 4 & GE110 & Gemlik $\times$ Edinciksu & 16 & GU439 & Gemlik $\times$ Uslu \\
\hline 5 & GE119 & Gemlik $\times$ Edinciksu & 17 & GT005 & Gemlik $\times$ Tavşan Yüreği \\
\hline 6 & GE181 & Gemlik $\times$ Edinciksu & 18 & GT009 & Gemlik $\times$ Tavşan Yüreği \\
\hline 7 & GE363 & Gemlik $\times$ Edinciksu & 19 & GT014 & Gemlik $\times$ Tavşan Yüreği \\
\hline 8 & GE366 & Gemlik $\times$ Edinciksu & 20 & BK013 & Belle d'Espagne $\times$ Karamürselsu \\
\hline 9 & GE417 & Gemlik $\times$ Edinciksu & 21 & LE003 & Lucques $\times$ Edinciksu \\
\hline 10 & GU247 & Gemlik $\times$ Uslu & 22 & LT019 & Lucques $\times$ Tavşan Yüreği \\
\hline 11 & GU320 & Gemlik $\times$ Uslu & 23 & ME015 & Manzanilla $\times$ Edinciksu \\
\hline 12 & GU323 & Gemlik $\times$ Uslu & & & \\
\hline
\end{tabular}


Principal component analysis was applied on the obtained data. The average of analysis result of the 3 years data was used in this analysis. Kinship tree was created using NTSYSPC 2.0 software package program, to show the degree of similarity. Genetic similarities were determined by using SAHN cluster analysis of UPGMA (Unweighted Pair-Group Method Algorithm).

\section{Results and Discussion}

High oil content and oil quality characteristics, with high fruit weight and flesh to seed ratio are reported as desired traits for new olive cultivar candidates. Fruit and seed dimensional characteristics (width and length), fruit weight and flesh to seed ratio are being used as descriptive fruit characters and thus are required for the new cultivar registration procedure for olive cultivar candidates in breeding studies. Measurements for these fruit characters of candidate cultivars tested within the current experiment are given in Table 2.

There were statistically significant differences $(\mathrm{p}<0.05)$ among all tested characters (Table 2). Fruit width, length, seed width, length, fruit weight and flesh to seed ratio were between $1.47 \mathrm{~cm}$ ('GT009') and $2.10 \mathrm{~cm}$ ('GE366); $1.83 \mathrm{~cm}$ ('GT009') and 3.07 cm ('BK013'); $0.73 \mathrm{~cm}$ ('GT009') and $0.98 \mathrm{~cm}$ ('GT014'); 1.30

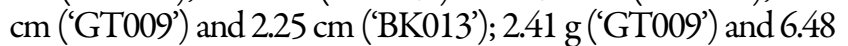
$\mathrm{g}$ ('BK013'); 3.34 'GE067') and 7.00 ('GE110') respectively. Fruit weight and flesh to seed ratio of standard national olive cultivars 'Ayvalik' and 'Gemlik' were 4.39 g; 3.55 g and 4.68; 4.97 (Table 2). Kumral et al. (2009) and Seyran (2009) determined weight of the 'Gemlik' fruit of 3.5 and $3.9 \mathrm{~g}$. Zeinanloo (2006) reported fruit weight of olive genotypes between 5.69-9.03 g, which were obtained within an olive breeding study. Fruit weight and flesh to seed ratio of 21 olive candidate cultivars were reported of $2.0-5.6 \mathrm{~g}$ and 3.6-8.1 (Padula et al., 2008). The current results were close to
Kumral et al. (2009), Seyran (2009) and Padula et al. (2008), but lesser than those of Zeinanloo (2006). According to flesh to seed ratio, 'GU358', 'GT009', 'GE110' and 'GE061' proved to have registration potential, while according to fruit weight and flesh to seed ratio 'ME015', 'BK013' and 'GE366' enhanced the highest potential for table olive production. Even so, according to the results of statistical analysis, these fruits were not found in the in highest oil content group. So that, regarding all cumulative data, those candidates were not appropriate to register for oil production.

Olive maturity is one of the important factors that significantly affects all characters of the fruits and oils (Owen et al., 2000). Therefore, maturity index was determined along with fruit and oil characters. Maturity index and oil and dry matter contents of genotypes are given in Table 3 .

There were statistically significant differences $(\mathrm{p}<0.05)$ for the oil percentage and dry matter among tested genotypes (Table 3). Dry matter content of olive genotypes was determined between $30.05 \%$ ('ME015') and 51.35\% ('GE181'). When compared with the results of Tanilgan et al. (2007) and Kumral et al. (2009), fruits of 'BK013', 'LE003', 'ME015' and 'GU323' genotypes (cultivar candidates) had lower dry matter content while the others had higher values.

Oil percentage of genotypes ranged from 12.20\% ('ME015') to $27.15 \%$ ('GU320') (Table 3). Olive oil percentage of 5 genotypes was reported between 40-50\% (in dry matter base) by Boulouha (2006). Zeinanloo et al. (2009) and Ripa et al. (2006) reported olive oil percentage of genotypes obtained by cross breeding, to be between $35.23 \%$ to $42.97 \%$ (in dry matter base) and $13.8 \%$ to $20.2 \%$ (in fresh weight base). Servili et al. (2006) reported that fruits of olives genotypes which had 48\% (in dry matter base) and higher oil percentage were useful for olive oil industry. Tous and Romero (1994) divided olives into three groups (based on oil percentage in dry matter) as high (> 46\%),

Table 2. Fruit and seed characteristics of tested olive genotypes and standard cultivars

\begin{tabular}{|c|c|c|c|c|c|c|}
\hline Genotype & $\begin{array}{l}\text { Fruit width } \\
(\mathrm{cm})\end{array}$ & $\begin{array}{c}\text { Fruit length } \\
(\mathrm{cm})\end{array}$ & $\begin{array}{l}\text { Seed width } \\
(\mathrm{cm})\end{array}$ & $\begin{array}{l}\text { Seed length } \\
(\mathrm{cm})\end{array}$ & $\begin{array}{c}\text { Fruit weight } \\
(\mathrm{g})\end{array}$ & $\begin{array}{c}\text { Flesh to seed } \\
\text { ratio }\end{array}$ \\
\hline GE061 & $1.70 \pm 0.20 \mathrm{~d}-\mathrm{h}$ & $1.90 \pm 0.17 \mathrm{gh}$ & $0.77 \pm 0.15$ & $1.37 \pm 0.06 \mathrm{ef}$ & $3.34 \pm 1.02 \mathrm{~d}-\mathrm{h}$ & $5.06 \pm 2.03$ \\
\hline GE067 & $1.60 \pm 0.10 \mathrm{e}-\mathrm{h}$ & $1.97 \pm 0.06 \mathrm{f}-\mathrm{h}$ & $0.85 \pm 0.09$ & $1.42 \pm 0.19 \mathrm{~d}-\mathrm{f}$ & $2.95 \pm 0.17 \mathrm{~d}-\mathrm{h}$ & $3.34 \pm 1.21$ \\
\hline GE073 & $1.80 \pm 0.17 \mathrm{~b}-\mathrm{g}$ & $2.13 \pm 0.15 \mathrm{~d}-\mathrm{h}$ & $0.81 \pm 0.01$ & $1.47 \pm 0.06 \mathrm{c}-\mathrm{f}$ & $3.69 \pm 0.97 \mathrm{c}-\mathrm{h}$ & $4.50 \pm 1.40$ \\
\hline GE110 & $1.87 \pm 0.15 a-f$ & $2.07 \pm 0.15 \mathrm{~d}-\mathrm{h}$ & $0.80 \pm 0.01$ & $1.33 \pm 0.06 f$ & $4.38 \pm 0.86 b-d$ & $7.00 \pm 2.20$ \\
\hline GE119 & $1.70 \pm 0.2 \mathrm{~d}-\mathrm{h}$ & $2.10 \pm 0.17 \mathrm{~d}-\mathrm{h}$ & $0.80 \pm 0.01$ & $1.43 \pm 0.06 \mathrm{~d}-\mathrm{f}$ & $3.87 \pm 0.82 b-f$ & $5.77 \pm 1.84$ \\
\hline GE181 & $1.57 \pm 0.12 \mathrm{fg}$ & $2.00 \pm 0.10 \mathrm{e}-\mathrm{h}$ & $0.81 \pm 0.07$ & $1.43 \pm 0.06 \mathrm{~d}-\mathrm{f}$ & $3.10 \pm 0.78 \mathrm{~d}-\mathrm{h}$ & $3.57 \pm 1.41$ \\
\hline GE363 & $1.70 \pm 0.1 \mathrm{~d}-\mathrm{h}$ & $2.00 \pm 0.10 \mathrm{e}-\mathrm{h}$ & $0.90 \pm 0.10$ & $1.43 \pm 0.12 \mathrm{~d}-\mathrm{f}$ & $3.55 \pm 0.05 c-h$ & $4.16 \pm 1.12$ \\
\hline GE366 & $2.10 \pm 0.10 \mathrm{ab}$ & $2.37 \pm 0.15 b-e$ & $0.97 \pm 0.06$ & $1.53 \pm 0.15 b-f$ & $5.27 \pm 0.11 \mathrm{ab}$ & $6.24 \pm 1.25$ \\
\hline GE417 & $1.65 \pm 0.07 \mathrm{e}-\mathrm{h}$ & $2.15 \pm 0.07 \mathrm{~d}-\mathrm{h}$ & $0.85 \pm 0.05$ & $1.60 \pm 0.00 \mathrm{~b}-\mathrm{f}$ & $3.45 \pm 0.35 c-h$ & $3.67 \pm 0.44$ \\
\hline GU247 & $1.60 \pm 0.20 \mathrm{e}-\mathrm{h}$ & $1.93 \pm 0.21 \mathrm{gh}$ & $0.78 \pm 0.08$ & $1.35 \pm 0.09 \mathrm{f}$ & $2.71 \pm 0.37 \mathrm{f}-\mathrm{h}$ & $4.41 \pm 0.72$ \\
\hline GU320 & $1.63 \pm 0.15 \mathrm{e}-\mathrm{h}$ & $2.37 \pm 0.21 b-e$ & $0.77 \pm 0.06$ & $1.55 \pm 0.05 b-f$ & $3.45 \pm 0.28 c-h$ & $4.54 \pm 0.49$ \\
\hline GU323 & $1.83 \pm 0.18 \mathrm{~b}-\mathrm{g}$ & $2.55 \pm 0.07 b c$ & $0.80 \pm 0.00$ & $1.77 \pm 0.06 b-c$ & $4.80 \pm 1.30 \mathrm{bc}$ & $4.98 \pm 0.73$ \\
\hline GU358 & $1.90 \pm 0.20 \mathrm{a}-\mathrm{e}$ & $2.13 \pm 0.21 \mathrm{~d}-\mathrm{h}$ & $0.85 \pm 0.09$ & $1.35 \pm 0.22 \mathrm{f}$ & $4.28 \pm 0.62 b-e$ & $5.37 \pm 1.50$ \\
\hline GU429 & $1.53 \pm 0.06 \mathrm{gh}$ & $1.90 \pm 0.00 \mathrm{gh}$ & $0.76 \pm 0.05$ & $1.31 \pm 0.18 \mathrm{f}$ & $2.29 \pm 0.20 \mathrm{~h}$ & $3.98 \pm 1.26$ \\
\hline GU434 & $1.87 \pm 0.12 \mathrm{a}-\mathrm{f}$ & $2.17 \pm 0.06 \mathrm{~d}-\mathrm{h}$ & $0.83 \pm 0.12$ & $1.47 \pm 0.15 c-f$ & $4.13 \pm 0.49 b-f$ & $5.29 \pm 1.76$ \\
\hline GU439 & $1.73 \pm 0.06 c-h$ & $2.33 \pm 0.06 b-f$ & $0.87 \pm 0.06$ & $1.57 \pm 0.06 b-f$ & $3.78 \pm 0.48 c-f$ & $4.45 \pm 1.51$ \\
\hline GT005 & $1.60 \pm 0.17 \mathrm{e}-\mathrm{h}$ & $2.00 \pm 0.20 \mathrm{e}-\mathrm{h}$ & $0.80 \pm 0.10$ & $1.40 \pm 0.20 \mathrm{~d}-\mathrm{f}$ & $2.86 \pm 0.97 \mathrm{e}-\mathrm{h}$ & $4.27 \pm 0.92$ \\
\hline GT009 & $1.47 \pm 0.15 \mathrm{~h}$ & $1.83 \pm 0.15 \mathrm{~h}$ & $0.73 \pm 0.06$ & $1.30 \pm 0.10 \mathrm{f}$ & $2.41 \pm 0.42 \mathrm{gh}$ & $5.04 \pm 1.40$ \\
\hline GT014 & $2.00 \pm 0.61 \mathrm{a}-\mathrm{d}$ & $2.63 \pm 0.85 b$ & $0.98 \pm 0.37$ & $1.81 \pm 0.72 b$ & $3.79 \pm 1.67 \mathrm{c}-\mathrm{f}$ & $4.35 \pm 1.18$ \\
\hline BK013 & $2.13 \pm 0.12 \mathrm{a}$ & $3.07 \pm 0.15 \mathrm{a}$ & $0.91 \pm 0.10$ & $2.25 \pm 0.13 a$ & $6.48 \pm 2.25 a$ & $6.15 \pm 0.67$ \\
\hline LE003 & $1.70 \pm 0.17 \mathrm{~d}-\mathrm{h}$ & $2.37 \pm 0.23 b-e$ & $0.82 \pm 0.10$ & $1.67 \pm 0.06 \mathrm{~b}-\mathrm{e}$ & $3.85 \pm 1.14 b-f$ & $4.56 \pm 1.61$ \\
\hline LT019 & $1.80 \pm 0.00 \mathrm{~b}-\mathrm{g}$ & $2.40 \pm 0.14 b-d$ & $0.80 \pm 0.10$ & $1.70 \pm 0.00 \mathrm{~b}-\mathrm{d}$ & $3.40 \pm 0.70 c-h$ & $4.31 \pm 1.50$ \\
\hline ME015 & $2.03 \pm 0.12 \mathrm{a}-\mathrm{c}$ & $2.20 \pm 0.17 \mathrm{c}-\mathrm{h}$ & $0.83 \pm 0.06$ & $1.47 \pm 0.06 c-f$ & $5.23 \pm 0.64 \mathrm{ab}$ & $6.26 \pm 0.66$ \\
\hline Ayvalık & $1.87 \pm 0.15 a-f$ & $2.43 \pm 0.21 b-d$ & $0.83 \pm 0.12$ & $1.67 \pm 0.21 b-e$ & $4.39 \pm 0.82 b-d$ & $4.68 \pm 0.99$ \\
\hline Gemlik & $1.70 \pm 0.28 \mathrm{e}-\mathrm{h}$ & $2.23 \pm 0.21 \mathrm{c}-\mathrm{g}$ & $0.90 \pm 0.01$ & $1.45 \pm 0.07 c-f$ & $3.55 \pm 0.92 c-h$ & $4.97 \pm 0.84$ \\
\hline
\end{tabular}


150

moderate (38 - 46\%) and low (<38\%). In the current research, all olives of candidate cultivars had the oil percentage higher than $38 \%$ (in dry matter base). According to the oil percentage in the dry matter base, 16 candidate cultivars were in "high" class, while 7

Table 3. Maturity index, dry matter and oil content of tested olive genotypes and standard cultivars

\begin{tabular}{cccc}
\hline Genotype & Maturity index & Dry matter $(\%)$ & Oil content $(\%)$ \\
\hline GE061 & 4.63 & $40.12 \pm 12.36$ & $17.77 \pm 2.43 \mathrm{~b}-\mathrm{e}$ \\
\hline GE067 & 3.24 & $43.28 \pm 0.48$ & $23.30 \pm 6.14 \mathrm{a}-\mathrm{c}$ \\
\hline GE073 & 4.75 & $47.34 \pm 5.17$ & $19.00 \pm 3.31 \mathrm{~b}-\mathrm{d}$ \\
\hline GE110 & 4.54 & $36.72 \pm 6.54$ & $19.42 \pm 4.74 \mathrm{~b}-\mathrm{d}$ \\
\hline GE119 & 4.16 & $43.57 \pm 4.15$ & $19.99 \pm 2.10 \mathrm{~b}-\mathrm{d}$ \\
\hline GE181 & 4.20 & $51.35 \pm 12.47$ & $23.97 \pm 5.72 \mathrm{ab}$ \\
\hline GE363 & 4.05 & $39.29 \pm 2.34$ & $16.46 \pm 0.96 \mathrm{de}$ \\
\hline GE366 & 4.95 & $44.58 \pm 5.12$ & $22.52 \pm 1.20 \mathrm{a}-\mathrm{d}$ \\
\hline GE417 & 3.74 & $43.72 \pm 3.11$ & $22.16 \pm 5.23 \mathrm{a}-\mathrm{d}$ \\
\hline GU247 & 3.80 & $41.34 \pm 4.98$ & $22.48 \pm 4.08 \mathrm{a}-\mathrm{d}$ \\
\hline GU320 & 4.43 & $43.70 \pm 5.81$ & $27.15 \pm 9.18 \mathrm{a}$ \\
\hline GU323 & 5.47 & $33.35 \pm 0.15$ & $20.18 \pm 2.70 \mathrm{~b}-\mathrm{d}$ \\
\hline GU358 & 4.67 & $37.53 \pm 4.24$ & $19.84 \pm 4.15 \mathrm{~b}-\mathrm{d}$ \\
GU429 & 5.23 & $41.09 \pm 10.06$ & $18.81 \pm 3.28 \mathrm{~b}-\mathrm{d}$ \\
\hline GU434 & 4.40 & $43.47 \pm 7.00$ & $21.89 \pm 3.45 \mathrm{a}-\mathrm{d}$ \\
\hline GU439 & 4.88 & $40.06 \pm 9.55$ & $18.76 \pm 1.45 \mathrm{~b}-\mathrm{e}$ \\
\hline GT005 & 3.89 & $44.42 \pm 7.73$ & $16.99 \pm 3.08 \mathrm{c}-\mathrm{e}$ \\
\hline GT009 & 4.38 & $44.44 \pm 4.98$ & $24.14 \pm 4.32 \mathrm{ab}$ \\
\hline GT014 & 3.72 & $39.29 \pm 2.62$ & $21.02 \pm 3.50 \mathrm{a}-\mathrm{d}$ \\
\hline BK013 & 3.42 & $34.04 \pm 3.00$ & $15.98 \pm 2.37 \mathrm{de}$ \\
\hline LE003 & 3.33 & $33.18 \pm 6.82$ & $17.12 \pm 6.04 \mathrm{c}-\mathrm{e}$ \\
\hline LT019 & 2.87 & $39.48 \pm 4.14$ & $17.26 \pm 0.99 \mathrm{c}-\mathrm{e}$ \\
\hline ME015 & 5.21 & $30.05 \pm 4.11$ & $12.20 \pm 2.32 \mathrm{e}$ \\
\hline Ayvalik & 3.17 & $41.75 \pm 9.85$ & $21.55 \pm 0.90 \mathrm{a}-\mathrm{d}$ \\
\hline Gemlik & 5.22 & $46.03 \pm 12.51$ & $23.09 \pm 5.29 \mathrm{a}-\mathrm{d}$ \\
\hline Different letters & in the same column refers to the & statistical difference \\
(p<0.05). & & & \\
\hline
\end{tabular}

candidate cultivars were in the "moderate" oil percentage groups respectively. 'GE067' (23.30\%), 'GE181' (23.97\%), 'GE366' (22.52\%), 'GE417’ (22.16\%), 'GT009’ (24.14\%), 'GT014' (21.02\%), 'GU247' (22.48\%), 'GU320' (27.15\%) and 'GU434' $(21.89 \%)$ candidate cultivars were figured in the same statistical group with 'Gemlik' and 'Ayvallk', which were the most common olive cultivars for oil production in Turkey (Table 4). These candidate cultivars had higher oil content than other candidates which were grown in same conditions. According to oil content, 'GE067', 'GE181', 'GE366, 'GE417', 'GT009', 'GT014', 'GU247', 'GU320' and 'GU434' are promising for registration as a new cultivars proper for oil production. Fruits of 'GE181' had high oil content, fact favorable from the environmental point of view as it reduces the amount of wastewater produced, which is the most threatening environmental pollutant of olive oil industry.

In order to define the oil characters of candidate cultivars, free fatty acid ratio, peroxide value, specific absorption value at ultraviolet light and chlorophyll content of oil samples were determined and results are given in Table 4. Free fatty acid ratio, peroxide value and chlorophyll value were between 0.47 ('LE003') and 0.98 ('ME015'); 3.70 ('LT019') and $9.01 \mathrm{meqO}_{2} / \mathrm{kg}$ ('ME015'); 0.11 ('GU320') and $0.63 \mathrm{mg} / \mathrm{kg}$ ('GE363') (Table 4). There were significant statistical differences among genotypes in terms of peroxide value and chlorophyll content $(\mathrm{p}<0.05)$. Olive oil is characterized by high oleic acid content (Ollivier et al., 2003). Free acidity of extra virgin and virgin olive oil expressed as oleic acid, should not be more than $0.8 \%$ and $2.0 \%$, respectively (Anonymous, 2015). According to free fatty acid content, 'GU320', GU439, GT005, 'GU434' and 'ME015' fit to virgin olive oil, while the rest of the oil samples fit to extra virgin olive oil category (Anonymous, 2015). Diraman (2007) and Kiralan et al. (2009) reported peroxide value of olive oils of different cultivars

Table 4. Free fatty acid content, peroxide value, specific absorption at ultraviolet light and amount of chlorophyll in oil of tested olive genotypes and standard cultivars

\begin{tabular}{|c|c|c|c|c|c|}
\hline \multirow{2}{*}{ Genotype } & \multirow{2}{*}{$\begin{array}{l}\text { Free fatty acid } \\
\text { (oleic acid \%) }\end{array}$} & \multirow{2}{*}{$\begin{array}{l}\text { Peroxide value } \\
\left(\mathrm{meqO}_{2} / \mathrm{kg}\right)\end{array}$} & \multicolumn{2}{|c|}{ Specific absorption at ultraviolet light } & \multirow{2}{*}{$\begin{array}{l}\text { Chlorophyll } \\
(\mathrm{mg} / \mathrm{kg})\end{array}$} \\
\hline & & & $232 \mathrm{~nm}$ & $270 \mathrm{~nm}$ & \\
\hline GE061 & $0.63 \pm 0.21$ & $4.21 \pm 0.80 \mathrm{~h}_{1}$ & $2.43 \pm 0.37$ & $0.20 \pm 0.04$ & $0.35 \pm 0.11 \mathrm{~b}-\mathrm{f}$ \\
\hline GE067 & $0.67 \pm 0.1$ & $6.45 \pm 0.79 \mathrm{~d}-\mathrm{g}$ & $2.62 \pm 0.44$ & $0.23 \pm 0.07$ & $0.18 \pm 0.13$ \\
\hline GE073 & $0.70 \pm 0.15$ & $5.71 \pm 1.28 \mathrm{~d}-1$ & $2.08 \pm 0.23$ & $0.20 \pm 0.05$ & $0.52 \pm 0.34 \mathrm{ab}$ \\
\hline GE110 & $0.76 \pm 0.20$ & $5.32 \pm 0.35 \mathrm{e}-1$ & $2.19 \pm 0.26$ & $0.21 \pm 0.08$ & $0.36 \pm 0.06 \mathrm{~b}-\mathrm{g}$ \\
\hline GE119 & $0.67 \pm 0.33$ & $4.75 \pm 0.43 f-1$ & $2.32 \pm 0.48$ & $0.20 \pm 0.03$ & $0.38 \pm 0.18 b-e$ \\
\hline GE181 & $0.66 \pm 0.03$ & $5.74 \pm 0.56 \mathrm{~d}-\mathrm{h}$ & $2.24 \pm 0.41$ & $0.20 \pm 0.04$ & $0.21 \pm 0.12 \mathrm{e}-\mathrm{g}$ \\
\hline GE363 & $0.52 \pm 0.06$ & $6.80 \pm 1.57 \mathrm{~b}-\mathrm{e}$ & $2.27 \pm 0.08$ & $0.23 \pm 0.01$ & $0.63 \pm 0.06 a$ \\
\hline GE366 & $0.66 \pm 0.26$ & $7.37 \pm 1.45 \mathrm{a}-\mathrm{d}$ & $2.15 \pm 0.45$ & $0.18 \pm 0.05$ & $0.23 \pm 0.13 \mathrm{e}-\mathrm{g}$ \\
\hline GE417 & $0.67 \pm 0.06$ & $5.72 \pm 0.47 \mathrm{~d}-\mathrm{h}$ & $2.33 \pm 0.39$ & $0.17 \pm 0.02$ & $0.36 \pm 0.07 b-f$ \\
\hline GU247 & $0.64 \pm 0.30$ & $7.51 \pm 2.74 a-d$ & $2.42 \pm 0.34$ & $0.27 \pm 0.02$ & $0.27 \pm 0.21 \mathrm{c}-\mathrm{g}$ \\
\hline GU320 & $0.97 \pm 0.56$ & $8.71 \pm 1.05 \mathrm{ab}$ & $2.53 \pm 0.48$ & $0.30 \pm 0.09$ & $0.11 \pm 0.09 \mathrm{~g}$ \\
\hline GU323 & $0.72 \pm 0.24$ & $7.24 \pm 0.67 \mathrm{a}-\mathrm{e}$ & $2.12 \pm 0.13$ & $0.17 \pm 0.03$ & $0.26 \pm 0.05 c-g$ \\
\hline GU358 & $0.53 \pm 0.17$ & $6.26 \pm 2.40 \mathrm{~d}-\mathrm{g}$ & $2.29 \pm 0.23$ & $0.21 \pm 0.06$ & $0.37 \pm 0.10 b-f$ \\
\hline GU429 & $0.73 \pm 0.23$ & $7.07 \pm 1.74 \mathrm{a}-\mathrm{e}$ & $2.33 \pm 0.33$ & $0.25 \pm 0.01$ & $0.21 \pm 0.04 \mathrm{e}-\mathrm{g}$ \\
\hline GU434 & $0.82 \pm 0.29$ & $6.55 \pm 0.85 c-f$ & $2.83 \pm 0.52$ & $0.22 \pm 0.08$ & $0.29 \pm 0.10 \mathrm{~b}-\mathrm{g}$ \\
\hline GU439 & $0.91 \pm 0.25$ & $7.28 \pm 1.90 \mathrm{a}-\mathrm{e}$ & $2.46 \pm 0.13$ & $0.26 \pm 0.15$ & $0.14 \pm 0.09 \mathrm{fg}$ \\
\hline GT005 & $0.82 \pm 0.39$ & $7.48 \pm 0.85 a-d$ & $2.06 \pm 0.29$ & $0.19 \pm 0.03$ & $0.44 \pm 0.26 \mathrm{a}-\mathrm{d}$ \\
\hline GT009 & $0.62 \pm 0.14$ & $4.48 \pm 0.66 \mathrm{~g}-1$ & $2.29 \pm 0.47$ & $0.18 \pm 0.05$ & $0.34 \pm 0.08 b-f$ \\
\hline GT014 & $0.58 \pm 0.18$ & $3.95 \pm 1.06 \mathrm{~h} 1$ & $2.20 \pm 0.10$ & $0.20 \pm 0.05$ & $0.18 \pm 0.12 \mathrm{e}-\mathrm{g}$ \\
\hline BK013 & $0.60 \pm 0.20$ & $5.28 \pm 1.14 \mathrm{e}-1$ & $2.79 \pm 0.48$ & $0.22 \pm 0.06$ & $0.36 \pm 0.19 b-f$ \\
\hline LE003 & $0.47 \pm 0.08$ & $4.09 \pm 0.57 \mathrm{~h}_{1}$ & $2.59 \pm 0.29$ & $0.19 \pm 0.03$ & $0.39 \pm 0.22 b-e$ \\
\hline LT019 & $0.71 \pm 0.13$ & $3.70 \pm 0.531$ & $2.32 \pm 0.18$ & $0.24 \pm 0.09$ & $0.23 \pm 0.03 \mathrm{~d}-\mathrm{g}$ \\
\hline ME015 & $0.98 \pm 0.82$ & $9.01 \pm 1.70 \mathrm{a}$ & $2.34 \pm 0.43$ & $0.26 \pm 0.08$ & $0.48 \pm 0.10 \mathrm{a}-\mathrm{c}$ \\
\hline Ayvalik & $0.70 \pm 0.30$ & $6.48 \pm 0.53 \mathrm{c}-\mathrm{g}$ & $2.32 \pm 0.23$ & $0.20 \pm 0.05$ & $0.22 \pm 0.09 \mathrm{~d}-\mathrm{g}$ \\
\hline Gemlik & $0.57 \pm 0.05$ & $8.12 \pm 1.15 \mathrm{a}-\mathrm{c}$ & $2.64 \pm 0.72$ & $0.21 \pm 0.05$ & $0.35 \pm 0.09 \mathrm{~b}-\mathrm{g}$ \\
\hline
\end{tabular}


from different regions of Turkey between 4.21-20.60 and 4.30$8.81 \mathrm{meqO} / \mathrm{kg}$. According to Trade Standard Applying to Olive Oils and Olive-Pomace Oil, peroxide value of extra virgin olive oil should not be more than $20 \mathrm{meqO}_{2} / \mathrm{kg}$. All of the samples had peroxide value lower than this limit.

Specific absorbance of olive oils at 232 and $270 \mathrm{~nm}$ is reported as a common character used for quality determination (Boskou, 2006). Biylklı (2009), Ilyasoglu and Ozcelik (2011) reported specific absorbance of olive oils at 232 and $270 \mathrm{~nm}$ to be between 1.95-2.67 and 0.123-0.420 respectively. Results of the current research were similar with these literature data. Beltran $e t$ al. (2005) determined the chlorophyll content of olive oil to be between $0.50-49.8 \mathrm{mg} / \mathrm{kg}$. Ranalli et al. (2000) reported the chlorophyll content of olive oils of an olive genotype (I-77) from three different regions as $8.8-12.7 \mathrm{mg} / \mathrm{kg}$. In this research, chlorophyll content of the olive oil was found to be between 0.11 to $0.63 \mathrm{mg} / \mathrm{kg}$, thus lower than the mentioned literature data.

Major and minor fatty acids compositions of olive oils are given in Tables 5 and 6. The most distinctive character of olive oil is fatty acid composition, which is used for identification and grouping of olive oils (Lee et al., 1998). Many different characteristics related with oxidative stability or nutritional physiology can be calculated by using distribution of fatty acids of olive oil (Kyriakidis and Katsiloulis, 2000). High MUFA and MUFA/PUFA correlated with low LA/LNA values are important for stability of oil against oxidation and for the beneficial effect on consumers (Kiritsakis et al., 1998). Thus SFA, MUFA, PUFA, MUFA/PUFA, LA/LNA and IN values of candidate cultivars were calculated. The obtained values are given in Table 7 .

Major fatty acids such as palmitic acid (9.87-12.69\%), palmitoleic acid (0.64-1.30\%), stearic acid (1.48-3.51\%), oleic acid (67.99-78.66\%), linoleic acid (4.59-12.94\%), arachidic acid (0.23$0.42 \%)$, linolenic acid (0.52-0.81\%), eicosenoic acid (0.19-0.28\%) and behenic acid (0.05-0.14\%) were determined (Table 5).
Fatty acid composition is one of the key parameters used to characterize olive oils. The unique fatty acid composition of olive oil is distinguished from other vegetable oil with this feature (Lee $e t$ al., 1998). Furthermore, distribution is also effective on oxidative stability and nutritional physiology (Owen et al., 2000). Sánchez de Medina et al. (2015) reported that oleic and palmitic acid content in olive oil is critical for the quality and fatty acid composition, thus it has been reported to be an important parameter used to decide the selection of olive genotypes in olive breeding programs.

Oleic acid/linoleic acid and MUFA/PUFA parameter is seen as an important indicator for oxidative stability of olive oil (Kiritsakis et al., 1998). Most studies referring to nutrients needed for a healthy life recommend the consumption of fatty acids in the form of omega-6/omega-3 fatty acid ratio which is desired to be approximately 1 (Stoll, 2001; Simopoulos, 2002), whereas the ratio of dietary habits in Western countries was reported as $15 / 1$ to 16.7/1 (Simopoulos, 2002; Allport, 2007). For olive oils, omega6/omega-3 fatty acid ratio is depending on LA/LNA ratio (Simopoulos, 2008). In this research, GE363 had a remarkable balance on LA and LNA results, with a ratio of 5.67, which represent an important feature in terms of disease prevention.

Telli Karaman et al. (2010) reported MUFA/PUFA, LA/LNA and IN of olive oils extracted from genotypes obtained from 'Gemlik' × 'Memecik' cross to be between 4.55-13.85\%, 8.35-19.08\% and 82.07-95.00\%, respectively. In this research, SFA, MUFA, PUFA, MUFA/PUFA, LA/LNA and IN of olive oil belonging to the candidate cultivars were detected between 12.33$16.36 \%, 68.90-79.30 \%, 6.67-16.36 \%, 4.21-14.69 \%, 5.67-19.97 \%$ and $79.66-86.51 \%$, respectively. Olive oil of 'GE363' had highest MUFA (79.30\%) and MUFA/PUFA (14.69\%) and the lowest LA/LN (5.67\%) values. Highest PUFA and lowest IN results were detected in olive oils of 'GE067' and 'GU434'. Olive oils of all candidate cultivars tested in the current study had lower IN than cv.'Ayvalk'.

Table 5. Major fatty acids in oil (\%) of tested olive genotypes and standard cultivars

\begin{tabular}{|c|c|c|c|c|c|}
\hline Genotype & $\begin{array}{c}\text { Palmitic } \\
\text { acid }\end{array}$ & $\begin{array}{c}\text { Palmitoleic } \\
\text { acid }\end{array}$ & $\begin{array}{c}\text { Stearic } \\
\text { acid }\end{array}$ & $\begin{array}{l}\text { Oleic } \\
\text { acid }\end{array}$ & $\begin{array}{c}\text { Linoleic } \\
\text { acid }\end{array}$ \\
\hline GE061 & $11.06 \pm 0.43 \mathrm{ef}$ & $0.76 \pm 0.08 \mathrm{e}-\mathrm{h}$ & $2.90 \pm 0.25 b-d$ & $75.48 \pm 3.02 \mathrm{a}-\mathrm{f}$ & $8.40 \pm 2.23 \mathrm{c}-\mathrm{f}$ \\
\hline GE067 & $11.58 \pm 0.51 \mathrm{c}-\mathrm{f}$ & $0.94 \pm 0.23 b-h$ & $2.48 \pm 1.30 \mathrm{c}-\mathrm{e}$ & $75.82 \pm 1.88 \mathrm{a}-\mathrm{e}$ & $5.62 \pm 1.12 \mathrm{gh}$ \\
\hline GE073 & $12.06 \pm 0.80 \mathrm{~b}-\mathrm{e}$ & $1.10 \pm 0.28 \mathrm{a}-\mathrm{d}$ & $2.68 \pm 0.40 \mathrm{~b}-\mathrm{e}$ & $76.65 \pm 0.22 \mathrm{a}-\mathrm{d}$ & $5.89 \pm 0.21 \mathrm{f}-\mathrm{h}$ \\
\hline GE110 & $12.26 \pm 1.41 \mathrm{~b}-\mathrm{e}$ & $1.30 \pm 0.16 \mathrm{a}$ & $2.22 \pm 0.61 c-f$ & $73.13 \pm 1.78 b-1$ & $9.86 \pm 0.91 \mathrm{~b}-\mathrm{e}$ \\
\hline GE119 & $11.79 \pm 0.27 \mathrm{~d}-\mathrm{f}$ & $0.94 \pm 0.21 b-h$ & $2.18 \pm 0.24 c-f$ & $73.04 \pm 2.59 \mathrm{~b}-1$ & $10.74 \pm 1.69 \mathrm{~b}-\mathrm{d}$ \\
\hline GE181 & $11.47 \pm 0.86 b-f$ & $0.77 \pm 0.07 \mathrm{~d}-\mathrm{h}$ & $2.96 \pm 0.09 \mathrm{~b}-\mathrm{d}$ & $74.43 \pm 1.52 \mathrm{a}-\mathrm{h}$ & $8.65 \pm 0.64 c-f$ \\
\hline GE363 & $11.90 \pm 0.80 \mathrm{~b}-\mathrm{f}$ & $0.64 \pm 0.05 \mathrm{~h}$ & $2.65 \pm 0.44 b-e$ & $78.66 \pm 1.39 a$ & $4.59 \pm 0.54 \mathrm{~h}$ \\
\hline GE366 & $12.14 \pm 0.30 \mathrm{~b}-\mathrm{e}$ & $1.08 \pm 0.24 \mathrm{a}-\mathrm{e}$ & $2.88 \pm 0.16 b-d$ & $72.86 \pm 2.59 \mathrm{~b}-1$ & $9.35 \pm 1.99 b-f$ \\
\hline GE417 & $12.03 \pm 1.19 \mathrm{~b}-\mathrm{e}$ & $1.23 \pm 0.35 \mathrm{a}-\mathrm{c}$ & $2.17 \pm 0.19 c-f$ & $76.42 \pm 2.55 \mathrm{a}-\mathrm{d}$ & $7.10 \pm 1.38 \mathrm{~d}-\mathrm{h}$ \\
\hline GU247 & $11.85 \pm 0.44 b-f$ & $0.99 \pm 0.09 \mathrm{a}-\mathrm{g}$ & $2.11 \pm 0.64 d-f$ & $76.76 \pm 0.70 \mathrm{a}-\mathrm{c}$ & $6.35 \pm 0.47 \mathrm{e}-\mathrm{h}$ \\
\hline GU320 & $12.70 \pm 0.72 \mathrm{ab}$ & $1.24 \pm 0.12 \mathrm{ab}$ & $1.48 \pm 0.26 f$ & $70.41 \pm 3.60 \mathrm{~h}-\mathrm{j}$ & $11.56 \pm 3.15 b c$ \\
\hline GU323 & $10.88 \pm 0.79 \mathrm{fg}$ & $1.01 \pm 0.07 \mathrm{a}-\mathrm{f}$ & $2.57 \pm 0.39 c-e$ & $74.97 \pm 0.42 \mathrm{a}-\mathrm{g}$ & $6.06 \pm 0.67 \mathrm{f}-\mathrm{h}$ \\
\hline GU358 & $12.15 \pm 0.22 \mathrm{~b}-\mathrm{e}$ & $0.75 \pm 0.28 \mathrm{e}-\mathrm{h}$ & $3.45 \pm 1.64 \mathrm{ab}$ & $71.24 \pm 4.46 f-j$ & $10.66 \pm 6.50 \mathrm{~b}-\mathrm{d}$ \\
\hline GU429 & $9.87 \pm 0.46 \mathrm{~g}$ & $0.93 \pm 0.18 b-h$ & $2.12 \pm 0.34 \mathrm{~d}-\mathrm{f}$ & $76.95 \pm 2.10 \mathrm{ab}$ & $8.56 \pm 1.47 c-f$ \\
\hline GU434 & $11.87 \pm 0.20 b-f$ & $0.91 \pm 0.08 b-h$ & $2.19 \pm 0.22 \mathrm{c}-\mathrm{f}$ & $67.99 \pm 2.50 \mathrm{j}$ & $15.58 \pm 2.00 \mathrm{a}$ \\
\hline GU439 & $12.61 \pm 1.13 \mathrm{bc}$ & $1.30 \pm 0.46 \mathrm{a}$ & $2.43 \pm 0.33 c-e$ & $72.56 \pm 6.42 c-1$ & $8.43 \pm 3.74 c-f$ \\
\hline GT005 & $12.12 \pm 0.254 \mathrm{~b}-\mathrm{e}$ & $1.10 \pm 0.29 a-d$ & $2.5 \pm 0.16 c-e$ & $74.00 \pm 3.28 \mathrm{~b}-\mathrm{h}$ & $9.01 \pm 2.13 c-f$ \\
\hline GT009 & $12.41 \pm 1.08 b-d$ & $0.90 \pm 0.23 c-h$ & $3.51 \pm 0.16 \mathrm{ab}$ & $72.06 \pm 2.66 \mathrm{e}-\mathrm{j}$ & $9.31 \pm 1.48 b-f$ \\
\hline GT014 & $11.13 \pm 0.68 \mathrm{~d}-\mathrm{f}$ & $0.73 \pm 0.10 \mathrm{f}-\mathrm{h}$ & $3.04 \pm 0.02 \mathrm{a}-\mathrm{c}$ & $74.07 \pm 0.98 \mathrm{~b}-\mathrm{h}$ & $9.46 \pm 1.47 \mathrm{~b}-\mathrm{f}$ \\
\hline BK013 & $12.69 \pm 0.24 \mathrm{ab}$ & $0.67 \pm 0.28 \mathrm{gh}$ & $2.57 \pm 0.25 c-e$ & $69.58 \pm 4.901-j$ & $12.94 \pm 4.44 \mathrm{ab}$ \\
\hline LE003 & $11.69 \pm 0.21 \mathrm{~b}-\mathrm{f}$ & $0.91 \pm 0.14 \mathrm{~b}-\mathrm{h}$ & $2.40 \pm 0.74 \mathrm{c}-\mathrm{e}$ & $73.34 \pm 0.16 b-1$ & $8.15 \pm 1.02 \mathrm{c}-\mathrm{h}$ \\
\hline LT019 & $11.41 \pm 0.65 \mathrm{~d}-\mathrm{f}$ & $0.93 \pm 0.26 b-h$ & $1.82 \pm 0.10 \mathrm{fe}$ & $74.18 \pm 0.01 b-h$ & $8.19 \pm 0.01 c-h$ \\
\hline ME015 & $11.68 \pm 0.74 b-f$ & $0.83 \pm 0.07 \mathrm{~d}-\mathrm{h}$ & $2.52 \pm 0.48 c-e$ & $72.37 \pm 0.31 \mathrm{~d}-1$ & $8.86 \pm 1.85 \mathrm{c}-\mathrm{f}$ \\
\hline Ayvalik & $13.74 \pm 0.84 \mathrm{a}$ & $1.00 \pm 0.12 \mathrm{a}-\mathrm{g}$ & $2.44 \pm 0.29 c-e$ & $70.92 \pm 1.81 \mathrm{~g}-\mathrm{j}$ & $10.27 \pm 1.28 b-d$ \\
\hline Gemlik & $11.90 \pm 0.04 \mathrm{~b}-\mathrm{e}$ & $0.89 \pm 0.13 \mathrm{~d}-\mathrm{h}$ & $3.66 \pm 0.30 \mathrm{a}$ & $73.79 \pm 0.66 \mathrm{~b}-1$ & $8.52 \pm 0.16 \mathrm{c}-\mathrm{f}$ \\
\hline
\end{tabular}


152

Table 6. Minor fatty acids in oil (\%) of tested olive genotypes and standard cultivars

\begin{tabular}{ccccc}
\hline Genotype & Arashidic acid & Linolenic acid & Eicosenoic acid & Behenic acid \\
\hline GE061 & $0.31 \pm 0.19$ & $0.68 \pm 0.12 \mathrm{a}-\mathrm{g}$ & $0.22 \pm 0.05$ & $0.12 \pm 0.04$ \\
GE067 & $0.42 \pm 0.19$ & $0.52 \pm 0.08 \mathrm{~h}$ & $0.21 \pm 0.03$ & $0.14 \pm 0.02$ \\
GE073 & $0.39 \pm 0.04$ & $0.64 \pm 0.02 \mathrm{c}-\mathrm{h}$ & $0.19 \pm 0.09$ & $0.10 \pm 0.03$ \\
GE110 & $0.38 \pm 0.25$ & $0.67 \pm 0.19 \mathrm{a}-\mathrm{f}$ & $0.23 \pm 0.02$ & $0.07 \pm 0.02$ \\
GE119 & $0.35 \pm 0.05$ & $0.68 \pm 0.06 \mathrm{a}-\mathrm{f}$ & $0.23 \pm 0.03$ & $0.13 \pm 0.01$ \\
GE181 & $0.42 \pm 0.03$ & $0.60 \pm 0.02 \mathrm{f}-\mathrm{h}$ & $0.22 \pm 0.02$ & $0.10 \pm 0.04$ \\
\hline GE363 & $0.35 \pm 0.04$ & $0.81 \pm 0.05 \mathrm{a}$ & $0.23 \pm 0.04$ & $0.11 \pm 0.01$ \\
\hline GE366 & $0.37 \pm 0.10$ & $0.66 \pm 0.05 \mathrm{~b}-\mathrm{h}$ & $0.20 \pm 0.06$ & $0.07 \pm 0.01$ \\
GE417 & $0.26 \pm 0.04$ & $0.65 \pm 0.11 \mathrm{c}-\mathrm{h}$ & $0.20 \pm 0.04$ & $0.13 \pm 0.02$ \\
GU247 & $0.33 \pm 0.07$ & $0.64 \pm 0.11 \mathrm{c}-\mathrm{h}$ & $0.28 \pm 0.02$ & $0.08 \pm 0.03$ \\
GU320 & $0.26 \pm 0.04$ & $0.76 \pm 0.08 \mathrm{a}-\mathrm{d}$ & $0.25 \pm 0.02$ & $0.13 \pm 0.03$ \\
GU323 & $0.25 \pm 0.06$ & $0.61 \pm 0.01 \mathrm{e}-\mathrm{h}$ & $0.22 \pm 0.01$ & $0.08 \pm 0.02$ \\
GU358 & $0.38 \pm 0.06$ & $0.63 \pm 0.13 \mathrm{~d}-\mathrm{h}$ & $0.23 \pm 0.10$ & $0.11 \pm 0.03$ \\
GU429 & $0.26 \pm 0.14$ & $0.69 \pm 0.09 \mathrm{a}-\mathrm{f}$ & $0.24 \pm 0.09$ & $0.12 \pm 0.06$ \\
GU434 & $0.26 \pm 0.16$ & $0.78 \pm 0.03 \mathrm{a}-\mathrm{c}$ & $0.22 \pm 0.08$ & $0.09 \pm 0.03$ \\
GU439 & $0.30 \pm 0.17$ & $0.76 \pm 0.06 \mathrm{a}-\mathrm{e}$ & $0.27 \pm 0.05$ & $0.12 \pm 0.05$ \\
GT005 & $0.25 \pm 0.14$ & $0.70 \pm 0.02 \mathrm{a}-\mathrm{f}$ & $0.19 \pm 0.06$ & $0.11 \pm 0.05$ \\
GT009 & $0.32 \pm 0.23$ & $0.68 \pm 0.13 \mathrm{a}-\mathrm{f}$ & $0.20 \pm 0.03$ & $0.13 \pm 0.06$ \\
GT014 & $0.37 \pm 0.14$ & $0.60 \pm 0.10 \mathrm{f}-\mathrm{h}$ & $0.24 \pm 0.04$ & $0.10 \pm 0.02$ \\
BK013 & $0.37 \pm 0.10$ & $0.80 \pm 0.17 \mathrm{ab}$ & $0.21 \pm 0.11$ & $0.10 \pm 0.01$ \\
LE003 & $0.23 \pm 0.06$ & $0.69 \pm 0.03 \mathrm{a}-\mathrm{f}$ & $0.22 \pm 0.12$ & $0.09 \pm 0.01$ \\
LT019 & $0.31 \pm 0.00$ & $0.71 \pm 0.01 \mathrm{a}-\mathrm{f}$ & $0.21 \pm 0.01$ & $0.12 \pm 0.05$ \\
ME015 & $0.37 \pm 0.01$ & $0.63 \pm 0.08 \mathrm{~d}-\mathrm{h}$ & $0.21 \pm 0.05$ & $0.10 \pm 0.07$ \\
Ayvalik & $0.43 \pm 0.02$ & $0.64 \pm 0.05 \mathrm{c}-\mathrm{h}$ & $0.23 \pm 0.11$ & $0.18 \pm 0.08$ \\
\hline Gemlik & $0.32 \pm 0.09$ & $0.54 \pm 0.01 \mathrm{gh}$ & &
\end{tabular}

Different letters in the same column refers to the statistical difference $(\mathrm{p}<0.05)$.

Table 7. Calculated important parameters by using fatty acid composition of olive oils

\begin{tabular}{|c|c|c|c|c|c|c|}
\hline \multirow{2}{*}{ Genotype } & \multicolumn{6}{|c|}{ Parameters* } \\
\hline & SFA & MUFA & PUFA & MUFA/PUFA & LA/LNA & IN \\
\hline GE061 & 14.39 & 76.24 & 9.08 & 8.40 & 12.35 & 83.52 \\
\hline GE067 & 14.62 & 76.76 & 6.14 & 12.50 & 10.81 & 79.66 \\
\hline GE073 & 15.23 & 77.75 & 6.53 & 11.91 & 9.20 & 81.09 \\
\hline GE110 & 14.93 & 74.43 & 10.53 & 7.07 & 14.72 & 83.29 \\
\hline GE119 & 14.45 & 73.98 & 11.42 & 6.48 & 15.79 & 84.42 \\
\hline GE181 & 14.98 & 75.20 & 9.25 & 8.13 & 14.42 & 82.67 \\
\hline GE363 & 15.00 & 79.30 & 5.40 & 14.69 & 5.67 & 81.69 \\
\hline GE366 & 15.50 & 73.94 & 10.01 & 7.39 & 14.17 & 82.30 \\
\hline GE417 & 14.53 & 77.65 & 7.75 & 10.02 & 10.92 & 82.54 \\
\hline GU247 & 14.42 & 77.75 & 6.99 & 11.12 & 9.92 & 81.90 \\
\hline GU320 & 14.52 & 71.65 & 12.32 & 5.82 & 15.21 & 83.31 \\
\hline GU323 & 13.75 & 75.98 & 6.67 & 11.39 & 9.93 & 79.71 \\
\hline GU358 & 16.11 & 71.99 & 11.29 & 6.38 & 16.92 & 82.51 \\
\hline GU429 & 12.33 & 77.88 & 9.25 & 8.42 & 12.41 & 85.15 \\
\hline GU434 & 14.43 & 68.90 & 16.36 & 4.21 & 19.97 & 86.51 \\
\hline GU439 & 15.46 & 73.86 & 9.19 & 8.04 & 11.09 & 81.10 \\
\hline GT005 & 14.96 & 75.10 & 9.71 & 7.73 & 12.87 & 82.99 \\
\hline GT009 & 16.36 & 72.96 & 9.99 & 7.30 & 13.69 & 81.55 \\
\hline GT014 & 14.65 & 74.80 & 10.06 & 7.44 & 15.77 & 83.45 \\
\hline BK013 & 15.76 & 70.25 & 13.74 & 5.11 & 16.18 & 84.47 \\
\hline LE003 & 14.42 & 74.25 & 8.84 & 8.40 & 11.81 & 81.22 \\
\hline LT019 & 13.64 & 75.11 & 8.90 & 8.44 & 11.54 & 82.10 \\
\hline ME015 & 14.66 & 73.20 & 9.49 & 7.71 & 14.06 & 81.11 \\
\hline Ayvalik & 16.73 & 71.92 & 10.91 & 6.59 & 16.05 & 81.71 \\
\hline Gemlik & 15.98 & 74.68 & 9.06 & 8.24 & 15.78 & 81.71 \\
\hline
\end{tabular}
number

As a result of principal component analysis of determined fruit and oil characteristics, tree diagram representation of component analysis were obtained (Fig. 1); plot of vector loadings on principal components 1 and 2 for fruit and oil characteristics are given in Fig. 2.

The tree diagram representation (Fig. 1) indicated that there were 3 groups of olive cultivars within the experiment. Group 1: 'GE061', 'LT019', 'GT014', 'GE067', 'GE417', 'GE073',
'GU429', 'GT005' and 'GE363'; Group 2: 'GE119', 'GE366, 'GT009', 'GU439', 'Ayvallk', 'Gemlik', 'GU320', 'GU434' and 'GE181' and Group 3: 'GE110', 'GU358, 'BK013', 'GU323', 'LE003' and 'ME015'.

The first component was positively correlated to fruit width, weight and length and negatively to dry matter. The second component was mainly positively associated with chlorophyll, stearic acid and oleic acid and negatively with absorbance value 


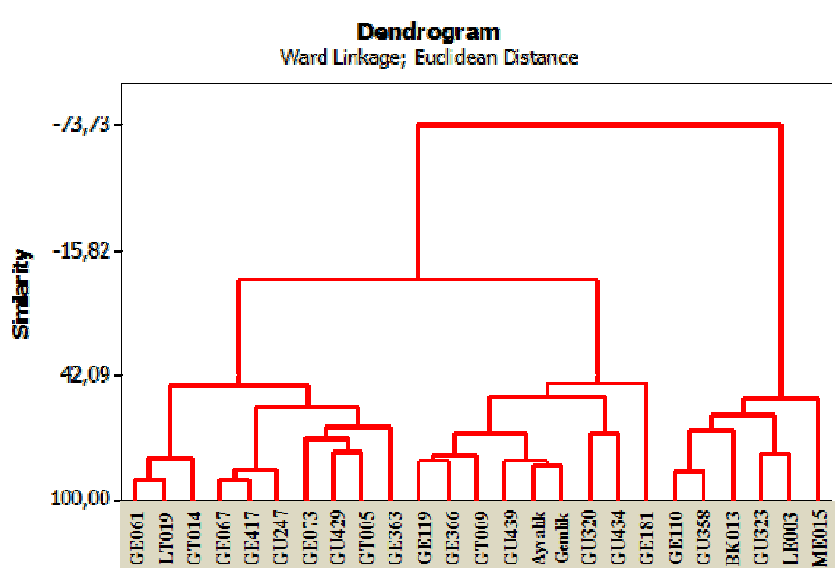

Fig. 1. Tree diagram representation of principal component analysis result of fruit and oil characteristics

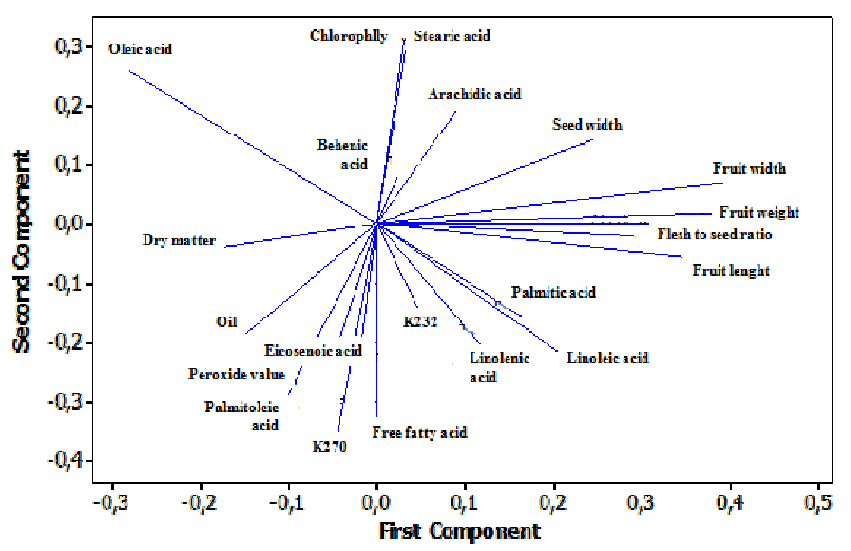

Fig. 2. Plot of vector loadings on principal components for fruit and oil characteristics

(K270) and free fatty acid content. These components therefore reflect the main correlation between the characters above mentioned (Fig. 2).

\section{Conclusion}

High fruit weight and flesh to seed ratio for table olives were preferred from consumers' perspective. So that, according to flesh to seed ratio, 'GU358, 'GE110', 'GE061' proved good potential for registration as table olive cultivar competitors, while according to fruit weight and flesh to seed ratio, 'ME015' and 'BK013' were suitable for table olive registration. Never the less, based on the oil percentage in dry matter, 'GE061' and 'ME015' were not appropriate to register for oil production, whereas 'GU358', 'GE110' and 'BK013' had high oil percentage in dry matter and thus they can be registered for dual purpose or for oil production. According to the overall evaluation of fruit and seed size, oil and free fatty acid content, peroxide value, specific absorption at ultraviolet light and fatty acid composition, 'GE366' and 'GU434' were determined as the best candidate cultivars, their fruits having the ability to be used as raw material for both table olive and olive oil industry. Olive oil of 'GE363' had the highest MUFA (79.30\%) and MUFA/PUFA (14.69\%) and the lowest LA/LNA (5.67\%) values, so that it comes forward for its oxidative stability and consumer nutrition physiology.

\section{Acknowledgments}

This work was supported by Ataturk Central Horticultural Research Institute and funded by the Ministry of Food, Agriculture and Livestock of Turkey (Project name: Oil Characteristics Determination of Some Hybrid Olives, Project no: TAGEM/HSGYAD/12/A05/P01/03).

\section{References}

Aktepe Tangu N, Akçay ME, Yalcnkaya E (2008). Olive variety development project. The first National Student Olive Congress, 17-18 May 2008, Balikesir, Turkey.

Allport S (2007). The queen of fats: why omega-3 fats were removed from the western diet and what we can do to replace them. Berkeley: University of California Press $115 \mathrm{p}$.

Anonymous (2015). Trade standard applying to olive oils and olive-pomace oils. International Olive Council, COI/T.15/NC No 3/Rev. 8 February 2015.

Arsel H, Cirik N (1994). A general overview of olive breeding in Turkey. Olivae 52:25-27.

Bellini E, Giordani E, Parlati MV, Pandolfi S (2002). Olive genetic improvement: thirty years of research. Acta Horticulturae 586:105-108.

Bellini E, Giordani E, Rosati A (2008). Genetic improvement of olive from clonal selection to cross-breeding programs. Advances Horticultural Science 22:73-86.

Beltran G, Aguilera MP, Del Rio C, Sanchez S, Marti Nez L (2005). Influence of fruit ripening process on the naturel antioxidant content of 'Hojiblanca' virgin olive oils. Food Chemistry 89:207-215.

Byylkı K (2009). Determination of the purity of the Turkish olive oil. Master of Science Thesis. Department of Food Engineering of Ankara University, Ankara, Turkey $77 \mathrm{p}$.

Boskou D (2006). Olive oil, chemistry and technology. American Oil Chemists' Society Press, New York 176p.

Boulouha B (2006). Acquired breeding in Morocco. CRRA Marrakech INRAMorocco.

Cemeroglu B (2007). Food analysis. Ankara: Bizim Büro Publication.

Diraman H (2007). Comparison of the oxidative stability of natural olive oil produced from Gemlik olives with other important indigenous cultivars. Electronic Journal Food Technology 3:53-59.

FAO - Food and Agriculture Organization of the United Nations (2012). FAOSTAT.21 May 2012. http://faostatfao.org/site/567/defaultaspx.

Hermoso M, Uceda M, Garc >a A, Morales B, Frias ML, Fernandez A (1991). Elaboracion de aceite de calidad. Consejeria de Agricultura y Pesca, Serie Apuntes 5/92, Sevilla.

Ilyasoglu H, Ozcelik B (2011). Biochemical characterization of olive oils belong to 'Memecik' cultivar. Gida36(1):33-41.

KailisSG,HarrisD (2007).Producingtable olives. Australia: Landlinks Pres.

Kaya H, Tekintaş FE (2006). Identification of Phenotypic Characteristics of local olive varieties Yamalak Sarns Grown in Aydin Province. ADU Faculty of Agriculture 3(2):17-22.

Kiralan AM, Bayrak A, Ozkaya MT (2009). Oxidation stability of virgin olive oils from some important cultivars in east Mediterranean area in Turkey.Journal of the American Oil Chemists' Society 86:247-252. 
154

Kiritsakis AK (1998). Composition of olive oil: Olive oil from the tree to the table. 2th Ed. Food \& Nutrition Press Inc USA.

Kumral A, Başoğlu F, Şahin I (2009). Effect of the use of different lactic starters on the microbiological and physicochemical characteristics of naturally black table olives of 'Gemlik' cultivar. Journal of Food Processingand Preservation 33:651-664.

Kyriakidis NB, Katsiloulis T (2000). Calculation of iodine value from measurements of fatty acid methyl esters of some oils: comparison with the relevant American oil chemists society method. Journal of the American Oil Chemists' Society 77:1235-1238.

Lavee S (1990). Aims, methods and advances in breeding of new olive (Olea europaea L.) cultivars. Acta Horticulturae 286:23-36.

Lavee S, Avidan B, Ben-Ari G (2014). Trends in breeding new olive varieties in Israel for quality and economic management. Agricultural Sciences 5:701-709.

Lee DS, Noh BS, Bae SY, Kim K (1998). Characterization of fatty acids composition in vegetable oils by gas chromatography and chemometrics. Analytica Chimica Acta 358(2):163-175.

Leon L, De la Rosa R, Gracia A, Barranco D, Rallo L (2008). Fatty acid composition of advanced olive selections obtained by crossbreeding. Journal of the Science of Food and Agriculture 88(11):1921-1926.

Leon L, Beltran G, Aguilera MP, Rallo L, Barranco D, De la Rosa, R(2011). Oil composition of advanced selections from an olive breeding program. European Journal of Lipid Science and Technology 113:870-875.

Ollivier D, Artaud J, Pinatel C, Durbec JP, Guérère M (2003). Triacylglycerol and fatty acid compositions of French virgin olive oils. Characterization by chemometrics. Journal of Agricultural Food Chemistry 51(19):5723-5731.

Owen RW, Giacosa A, Hull WE, Haubner R, Würtele G, Spiegelhalder B, Bartsch H (2000). Olive-oil consumption and health: the possible role of antioxidants. The Lancet Oncology 1(2):107-112.

Ozdemir Y, Akcay ME, Kurultay S (2011). Melezleme islahı ile elde edlen iki amaçlı (sofralık ve yağılk) zeytin çeşit adaylarina genel bir bakıs. Bahçe 40:29-36 (in Turkish).

Ozdemir Y, Aktepe Tangu N, Akcay ME (2013). Generating omega-3 rich olive oil by cross breeding. European Journal of Lipid Science and Technology 115:977-981.

Ozdemir Y, Kurultay S (2015). Physicochemical characteristics of advanced table olive selections at green and black ripeness obtained by crossbreeding. Agriculture and Food 3:21-31.

Padula G, Giordani E, Bellini E, Rosati A, Pandolfi S, Paoletti A, Pannelli G, Ripa V, De Rose F, Perri E, Buccoliero A, Mennone C (2008). Field evaluation of new olive (Olea europaea 1.) selections and effects of genotype and environment on productivity and fruit characteristics. Advances in Horticultural Science 22:87-94.

Pritsa TS, Voyiatzis DG, Voyiatzi CJ, Sotiriou MS (2003). Evaluation of vegetative growth traits and their relation to time to first flowering of olive seedlings. Australian Journal of Agricultural Research 54:371-376.
Ranalli A, Modesti G, Patumi M, Fontanazza G (2000). The compositional quality and sensory properties of virgin olive oil from a new olive cultivarI-77. Food Chemistry 69:37-46.

Ripa V, De Rose F, Tucci A, Scalercio S, Tucci P, Pellegrino M (2006). Preliminary observations on the agronomical behaviour of olive cross breedings cultivated in Rossano Calabro. Olivebioteq Symposium, 5-10 November 2006, Marsala, Italy, Vol 1:139-142.

Roca M, León L de la Rosa R (2011). Pigment metabolism of 'Sikitita' olive (Olea europaea L.): a new cultivar obtained by cross-breeding. Journal of Agricultural and Food Chemistry 59:2049-2055.

Sánchez De Medina V, El Riachy M, Priego-Capote F, Luque De Castro MD (2015). Composition of fatty acids in virgin olive oils from cross breeding segregating populations by gas chromatography separation with flame ionization detection. Journal of the Science of Food and Agriculture 95(14):2892-2900.

Servili M, Taticchi A, Veneziani G, Urbani S, Esposto S, Massitti O, Corsetti A, Montedoro GF (2006). Nuove tecnologie di deamarizzazione biologica per il miglioramento della qualità delle olive da tavola. Rivista di Frutticolturae Ortofloricoltura 3:22-26.

Seyran Ö (2009). Some physiological, morphological and biochemical changes during fruit growing of 'Silifke yağltk', 'Sarı ulak' and 'Gemlik' olive cultivars. Master of Science Thesis. Department of Food Engineering of Mustafa Kemal University, Hatay, Turkey.

Simopoulos AP (2002). The importance of the ratio of omega-6/omega-3 essential fatty acids. Biomedicine and Pharmacotheraphy 56(8):365-79.

Simopoulos AP (2008). The importance of the omega-6/omega-3 fatty acid ratio in cardiovascular disease and other chronic diseases. Experimental Biology and Medicine 233:674-688.

Stoll A (2001). The omega-3 connection. New York: Simon and Schuster, USA.

Tanilgan K, Özcan MM, Ünver A (2007). Physical and chemical characteristics of five Turkish olive (Olea europea L.) varieties and their oils. Grasasy Aceites 58:142-147.

Tous J, Romero A (1994). Cultivar and location effects on olive oil quality in Catalonia(Spain). ActaHorticulturae 356:323-326.

Trigui A (1996). Improving the quantity and quality of olive production in Tunisia: Unavoidable need and outlook for olive identification and breeding. Olivae 61:3440.

Telli Karaman H, Diraman H, Sefer F (2010). Oil characteristics determination of cultivar candidate obtained by cross breeding (TAGEM/GY/06/11/04/119, Publication No: 196).T.R. Ministry of Agriculture and Rural Affairs, Olive Research Institute, Izmir, Turkey.

TS 774 (1992). Turkish Standards Institute, Turkish Table Olive Standard. Ankara, Turkey.

Zeinanloo AA (2006). The olive industry in Iran. Recent advances in olive industry. Olivebioteq 173-182. 